\title{
Oxidation of Tertiary Silanes by Osmium Tetroxide
}

\author{
Karine Valliant-Saunders, ${ }^{\ddagger}$ Erica Gunn, ${ }^{\ddagger}$, G. Robert Shelton, ${ }^{\S}$ David A. Hrovat, ${ }^{\S}$ \\ Weston Thatcher Borden, ${ }^{\star, \S}$ and James M. Mayer ${ }^{\star \star \neq}$ \\ University of Washington, Department of Chemistry, Box 351700, Seattle, WA 98195-1700 \\ University of North Texas, Department of Chemistry, P.O. Box 305070, Denton, TX 76203-5070 \\ mayer@chem.washington.edu; borden@unt.edu
}

\section{Supporting Information (experimental)}

\section{Reactions of $\mathrm{OsO}_{4}(\mathrm{~L})$ with $\mathrm{R}_{3} \mathrm{SiH}$}

(A) $\mathrm{OsO}_{2}(\mathbf{p y})_{2}\left(\mathrm{OSiMe}_{2} \mathbf{P h}\right)(\mathbf{O H}) \cdot \mathrm{OsO}_{4}(117 \mathrm{mM})+$ py $(322 \mathrm{M})+\mathrm{PhMe}_{2} \mathrm{SiH}(117 \mathrm{mM})$ gave $\mathrm{OsO}_{2}(\mathrm{py})_{2}\left(\mathrm{OSiMe}_{2} \mathrm{Ph}\right)(\mathrm{OH})$. Spectra in the presence of py, $\left.\mathrm{PhMe} \mathrm{SiH}_{2} \mathrm{H}_{2} \mathrm{O}\right):{ }^{1} \mathrm{H} \mathrm{NMR}\left(\mathrm{CD}_{2} \mathrm{Cl}_{2}\right.$, $200 \mathrm{~K}): \delta 8.60(\mathrm{~d}, 2 \mathrm{H}, 7.0 \mathrm{~Hz}), 8.59(\mathrm{~m}, 2 \mathrm{H}), 7.73(\mathrm{~m}, 1 \mathrm{H}), 7.70(\mathrm{~m}, 1 \mathrm{H}), 7.38(\mathrm{~m}, 2 \mathrm{H}), 7.36(\mathrm{~m}$, 2H) py; $7.43(\mathrm{~m}, 2 \mathrm{H}), 7.20(\mathrm{~m}, 3 \mathrm{H}), 0.10(\mathrm{~s}, 6 \mathrm{H}) \mathrm{OSiPh} M e_{2} ; 8.2$ (s, $\left.1 \mathrm{H}\right) \mathrm{OsOH}$; and $2.0\left(\mathrm{H}_{2} \mathrm{O}\right)$. ${ }^{13} \mathrm{C}\left\{{ }^{1} \mathrm{H}\right\} \mathrm{NMR}\left(\mathrm{CD}_{2} \mathrm{Cl}_{2}, 200 \mathrm{~K}\right): 150.9,149.4,141.9,141.8,125.4,124.8$ (py); 142.0, 136.2, 128.3, $127.2\left(\mathrm{PhMe}_{2} \mathrm{Si}\right) ; 0.17\left(\mathrm{PhMe} \mathrm{S}_{2} \mathrm{Si}\right)$. Spiking with an authentic sample identified the $\mathrm{PhMe}_{2} \mathrm{SiOH}$ by ${ }^{1} \mathrm{H}$ NMR (yield $64 \pm 10 \%$ ).

(B) $\mathbf{O s O}_{2}(\mathbf{p y})_{2}\left(\mathbf{O S i E t}_{3}\right)(\mathbf{O H}) \cdot \mathrm{OsO}_{4}(111 \mathrm{mM})+$ py $(1.39 \mathrm{M})+\mathrm{Et}_{3} \mathrm{SiH}(111 \mathrm{mM})$ gave $\mathrm{OsO}_{2}(\mathrm{py})_{2}\left(\mathrm{OSiEt}_{3}\right)(\mathrm{OH}) .{ }^{1} \mathrm{H} \mathrm{NMR}\left(\mathrm{CD}_{2} \mathrm{Cl}_{2}, 200 \mathrm{~K}\right.$, in the presence of ${ }^{t} \mathrm{Bupy}$, water and silane): $\delta$ $8.83(\mathrm{~d}, 2 \mathrm{H}, 6.0 \mathrm{~Hz}), 8.65$ (d, 2H, $6.0 \mathrm{~Hz}), 7.83(\mathrm{~m}, 1 \mathrm{H}), 7.76(\mathrm{~m}, 1 \mathrm{H}), 7.45(\mathrm{~m}, 2 \mathrm{H}), 7.41(\mathrm{~m}$, 2H) py; $0.734(\mathrm{t}, 9 \mathrm{H}, 8.0 \mathrm{~Hz}), 0.269(\mathrm{q}, 6 \mathrm{H}, 8.0 \mathrm{~Hz}), \mathrm{OSiCH}_{2} \mathrm{CH}_{3} ; \delta 8.2(\mathrm{~s}, 1 \mathrm{H}) \mathrm{Os}-\mathrm{OH} .{ }^{13} \mathrm{C}\left\{{ }^{1} \mathrm{H}\right\}$ NMR $\left(\mathrm{CD}_{2} \mathrm{Cl}_{2}, 200 \mathrm{~K}\right.$, in the presence of py, silane and water: 149.6, 149.4, 141.2, 141.1, 125.4, 125.0, py; 7.11 $\mathrm{OSiCH}_{2} \mathrm{CH}_{3} ; 1.76 \mathrm{OSiCH}_{2} \mathrm{CH}_{3}$. An EXSY spectrum at $240 \mathrm{~K}$ showed exchange $\left(k \sim 38 \mathrm{~s}^{-1}\right.$ ) between $\delta 8.2$ and $\delta 2.8$ (the latter confirmed to be $\mathrm{H}_{2} \mathrm{O}$ by spiking). The production of $\mathrm{Et}_{3} \mathrm{SiOH}$ was confirmed by spiking the tube with an authentic sample and by GC/MS. GC/MS was performed by injection of $2 \mu \mathrm{L}$ of the supernatant of an un-spiked NMR tube reaction onto the $\mathrm{GC} / \mathrm{MS}$ column. The initial temperature was $40^{\circ} \mathrm{C}$ and the final temperature was $250^{\circ} \mathrm{C}$ with ramping by $10^{\circ} \mathrm{C} / \mathrm{min}$ : GC yield $48 \pm 2 \%$ based on a calibration curve. The overall yield with error reported in the body is an average of GC/MS and ${ }^{1} \mathrm{H}$ NMR yields with the error calculated from both sets of data.

(C) $\mathbf{O s O}_{2}(\mathbf{p y})_{2}\left(\mathbf{O S i}^{i} \mathbf{P r}_{3}\right)(\mathbf{O H}) . \quad \mathrm{OsO}_{4}(86 \mathrm{mM})+$ py $(849 \mathrm{mM})+{ }^{i} \mathrm{Pr}_{3} \mathrm{SiH}(86 \mathrm{mM})$ gave $\mathrm{OsO}_{2}(\mathrm{py})_{2}\left(\mathrm{OSi}^{i} \mathrm{Pr}_{3}\right)(\mathrm{OH}) .{ }^{1} \mathrm{H} \mathrm{NMR}\left(\mathrm{CD}_{2} \mathrm{Cl}_{2}, 200 \mathrm{~K}\right.$, in the presence of py): $\delta 8.82(\mathrm{~d}, 2 \mathrm{H}, 6.0$ 
Hz), 8.67 (d, 2H, $6.0 \mathrm{~Hz}), 7.86(\mathrm{~m}, 1 \mathrm{H}), 7.82(\mathrm{~m}, 1 \mathrm{H}), 7.48(\mathrm{~m}, 2 \mathrm{H}), 7.45$ (m, 2H) py; 0.90 (s, $18 \mathrm{H}) \mathrm{OSiC}\left(\mathrm{CH}_{3}\right)_{2} ; \delta 8.2$ (s, $\left.1 \mathrm{H}\right) \mathrm{Os}-\mathrm{OH} .{ }^{13} \mathrm{C}\left\{{ }^{1} \mathrm{H}\right\} \mathrm{NMR}\left(\mathrm{CD}_{2} \mathrm{Cl}_{2}, 200 \mathrm{~K}\right.$, in the presence of py, silane and water: $149.7,148.8,141.2,140.6,125.4,125.1$, py; $18.20 \mathrm{OSiC}\left(\mathrm{CH}_{3}\right)_{2} ; 14.06$ $\mathrm{OSiC}\left(\mathrm{CH}_{3}\right)_{2}$. The production of ${ }^{i} \mathrm{Pr}_{3} \mathrm{SiOH}$ was confirmed by spiking with an authentic sample and by GC/MS (as described procedure above): GC yield $52 \pm 2 \%$.

(D) $\mathbf{O s O}_{2}(\mathbf{p y})_{2}\left(\mathbf{O S i P h}_{3}\right)(\mathbf{O H}) . \quad \mathrm{OsO}_{4}(86 \mathrm{mM})+$ py $(849 \mathrm{mM})+\mathrm{Ph}_{3} \mathrm{SiH}(86 \mathrm{mM})$ gave $\mathrm{OsO}_{2}(\mathrm{py})_{2}\left(\mathrm{OSiPh}_{3}\right)(\mathrm{OH}) .{ }^{1} \mathrm{H} \mathrm{NMR}\left(\mathrm{CD}_{2} \mathrm{Cl}_{2}, 200 \mathrm{~K}\right.$, in the presence of py): $\delta 8.65(\mathrm{~d}, 2 \mathrm{H}, 6.0$ $\mathrm{Hz}), 8.64(\mathrm{~d}, 2 \mathrm{H}, 6.0 \mathrm{~Hz}), 7.78(\mathrm{~m}, 1 \mathrm{H}), 7.62(\mathrm{~m}, 1 \mathrm{H}), 7.32(\mathrm{~m}, 2 \mathrm{H}), 7.25(\mathrm{~m}, 2 \mathrm{H}) \mathrm{py} ; 7.56(\mathrm{~d}$, $2 \mathrm{H}, 8 \mathrm{~Hz}), 7.44(\mathrm{~m}, 1 \mathrm{H}), 7.40(\mathrm{~d}, 2 \mathrm{H}, 8 \mathrm{~Hz}) \mathrm{OSiPh}_{3} ; \delta 8.2(\mathrm{~s}, 1 \mathrm{H})$ Os-OH. ${ }^{13} \mathrm{C}\left\{{ }^{1} \mathrm{H}\right\} \mathrm{NMR}$ $\left(\mathrm{CD}_{2} \mathrm{Cl}_{2}, 200 \mathrm{~K}\right.$, in the presence of py, silane and water: 150.0, 148.3, $141.3140 .7,125.6,124.8$, py; $138.3(i), 135.0(m), 132.8(o), 129.0(p) \mathrm{OSiPh}_{3} ; . \mathrm{Ph}_{3} \mathrm{SiOH}$ was confirmed by spiking with an authentic sample: NMR yield $61 \pm 10 \%$.

(E) Reaction of $\mathrm{OsO}_{4}$ (py) with $\mathbf{R}_{3} \mathrm{SiH}$ in $\mathbf{C C l}_{4}$. An $\mathrm{NMR}$ tube was charged with $\mathrm{OsO}_{4}$ $(0.0138 \mathrm{~g}, 122 \mathrm{mM}), \mathrm{CCl}_{4}(400 \mu \mathrm{L})$ and pyridine- $d_{5}(44 \mu \mathrm{L}, 1.24 \mathrm{M}) . \mathrm{Et}_{3} \mathrm{SiH}(7 \mu \mathrm{L}, 98 \mathrm{mM})$ was added to the frozen solution and the reaction mixture was freeze-pump-thawed (3X) and flame sealed under $\mathrm{N}_{2}$. ${ }^{1} \mathrm{H}$ and ${ }^{13} \mathrm{C}\left\{{ }^{1} \mathrm{H}\right\}$ NMR spectra showed $\mathrm{Et}_{3} \mathrm{SiH}$ and $\mathrm{Et}_{3} \mathrm{SiOH}$ but not $\mathrm{Et}_{3} \mathrm{SiCl}$ (confirmed by spiking experiments). A control experiment with added $\mathrm{Et}_{3} \mathrm{SiCl}$ followed the same procedure and showed that the $\mathrm{Et}_{3} \mathrm{SiCl}$ was not consumed and did not affect the products formed. Similarly, $\mathrm{OsO}_{4}(256 \mathrm{mM}),{ }^{t} \mathrm{Bupy}(1.54 \mathrm{M}), \mathrm{PhMe}_{2} \mathrm{SiH}(256 \mathrm{mM})$, and $\mathrm{PhMe}_{2} \mathrm{SiCl}(256 \mathrm{mM})$ were reacted in $\mathrm{CCl}_{4}$ and ${ }^{1} \mathrm{H}$ NMR spectra showed $\mathrm{PhMe}_{2} \mathrm{SiOH}$ and no consumption of $\mathrm{PhMe}_{2} \mathrm{SiCl}$.

(F) $\mathbf{O s O}_{4}(\mathbf{p y})+\mathbf{E t}_{3} \mathbf{S i H}+\mathbf{C B r}_{4}$. Following the procedure above, $\mathrm{OsO}_{4}(50 \mathrm{mM})$, pyridine (300 mM), Et $\mathrm{EiH}_{3}(7 \mu \mathrm{L}, 98 \mathrm{mM})$ and $\mathrm{CBr}_{4}(0.020 \mathrm{~g}, 190 \mathrm{mM})$ were reacted in $\mathrm{CDCl}_{3}$. The final ${ }^{1} \mathrm{H}$ NMR spectra showed $\mathrm{Et}_{3} \mathrm{SiOH}$ peaks and there was no evidence for $\mathrm{Et}_{3} \mathrm{SiBr}$.

(G) $\mathrm{OsO}_{2}\left({ }^{t} \mathbf{B u p y}_{2}\left(\mathbf{O S i E t}_{3}\right)(\mathbf{O H}) . \quad \mathrm{OsO}_{4}(117 \mathrm{mM})+{ }^{t} \mathrm{Bupy}(752 \mathrm{mM})+\mathrm{Et}_{3} \mathrm{SiH}(115 \mathrm{mM})\right.$ gave $\mathrm{OsO}_{2}\left({ }^{t} \mathrm{Bupy}\right)_{2}\left(\mathrm{OSiEt}_{3}\right)(\mathrm{OH})$. The water peak was not apparent in the initial ${ }^{1} \mathrm{H} \mathrm{NMR}$ of $\mathrm{OsO}_{4}\left({ }^{t} \mathrm{Bupy}\right)$ so the tube was spiked with $10 \mu \mathrm{L} \mathrm{H}_{2} \mathrm{O}$. Spectra in the presence of $\left.{ }^{t} \mathrm{Bupy}, \mathrm{H}_{2} \mathrm{O}\right):{ }^{1} \mathrm{H}$ NMR $\left(\mathrm{CD}_{2} \mathrm{Cl}_{2}, 200 \mathrm{~K}\right): \delta 8.72$ (d, 2H, 6.5 Hz, py), 8.55 (d, 2H, $6.0 \mathrm{~Hz}$, py), 7.45 (d, 2H, $6.0 \mathrm{~Hz}$, py), $7.43(\mathrm{~d}, 2 \mathrm{H}, 7.0 \mathrm{~Hz}, \mathrm{py}), 1.30\left(\mathrm{~s}, 18 \mathrm{H},{ }^{t} \mathrm{Bu}\right) ; 0.735$ (t, 9H, $\left.8.0 \mathrm{~Hz}, \mathrm{CH}_{3}\right), 0.271$ (q, 6H, 8.0 $\left.\mathrm{Hz}, \mathrm{CH}_{2}\right) \mathrm{OSiEt}_{3} ; 8.3(\mathrm{~s}, 1 \mathrm{H}) \mathrm{Os}-\mathrm{OH}$; and $4.3\left(\mathrm{~s}, \mathrm{H}_{2} \mathrm{O}\right)$. COSY and EXSY spectra were obtained; the latter at $220 \mathrm{~K}$ showed exchange $\left(k \sim 9 \mathrm{~s}^{-1}\right)$ between $\delta 8.3$ and $\delta 4.3 .{ }^{13} \mathrm{C}\left\{{ }^{1} \mathrm{H}\right\} \mathrm{NMR}$ 
$\left(\mathrm{CD}_{2} \mathrm{Cl}_{2}, 200 \mathrm{~K}\right): 165.9,165.7,148.8,148.2,122.8,122.6$, py; 34.8, 33.6 $\mathrm{Me}_{3} C ; 31.2,29.9 \mathrm{Me}_{3} \mathrm{C}$ py; $7.11 \mathrm{SiCH}_{2} \mathrm{CH}_{3} ; 1.76 \mathrm{SiCH}_{2} \mathrm{CH}_{3}$. Spiking with an authentic sample confirmed the presence of $\mathrm{Et}_{3} \mathrm{SiOH}$.

(H) $\mathrm{OsO}_{4}(\mathrm{~L})$ plus other reducing agents. In a typical procedure, an NMR tube was loaded with $400 \mu \mathrm{L}$ of an $\mathrm{OsO}_{4}$ solution $\left(0.1488 \mathrm{~g}\right.$ in $\left.5 \mathrm{~mL} \mathrm{CD} \mathrm{Cl}_{2}, 117 \mathrm{mM}\right), 50 \mu \mathrm{L}$ of py $(1.39 \mathrm{M})$ or ${ }^{t}$ Bupy $(752 \mathrm{mM})$. After an initial NMR spectrum at $200 \mathrm{~K}, 12 \mu \mathrm{L}$ of a cold 4,4,5,5-pinacolborane solution ( $0.426 \mathrm{~g}$ in $1 \mathrm{~mL} \mathrm{CD} \mathrm{Cl}_{2}, 3.32 \mathrm{M}$ ) was added by glass syringe. Another ${ }^{1} \mathrm{H}$ NMR spectrum was obtained and formation of black solids was observed within minutes. The reactions of 9-BBN, $\mathrm{Bu}_{3} \mathrm{SnH}$, and $\mathrm{PhSiH}_{3}$ proceeded similarly.

Figure S1. Decay of the intermediate at $298 \mathrm{~K}$ in $\mathrm{CD}_{2} \mathrm{Cl}_{2}$ as a function of time (s). Concentrations of $\mathrm{OsO}_{4}, 4-{ }^{t} \mathrm{Bupy}$ and $\mathrm{PhMe}_{2} \mathrm{SiH}$ are: $0.025 \mathrm{M}, 0.863 \mathrm{M}$ and $0.136 \mathrm{M}$.

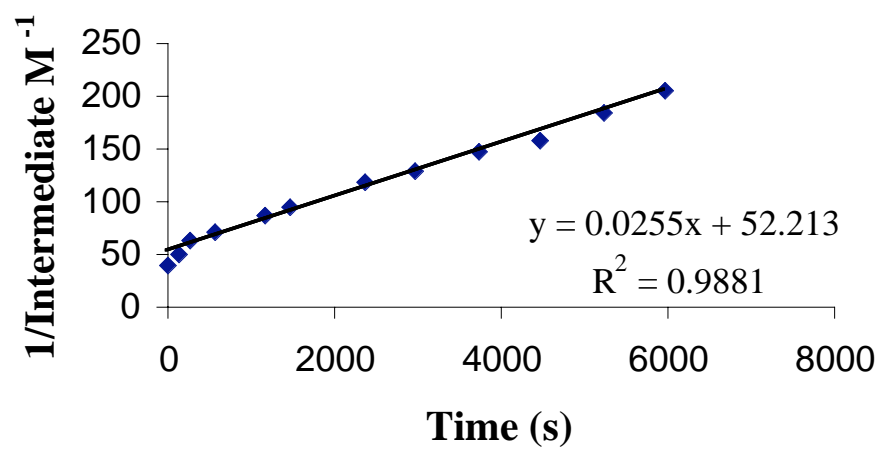

Figure S2. Decay of the intermediate at $298 \mathrm{~K}$ in $\mathrm{CD}_{2} \mathrm{Cl}_{2}$ as a function of time (s). Concentrations of $\mathrm{OsO}_{4}, 4{ }^{t} \mathrm{Bupy}$ and $\mathrm{PhMe}_{2} \mathrm{SiH}$ are: $0.020 \mathrm{M}, 0.863 \mathrm{M}$ and $0.136 \mathrm{M}$.

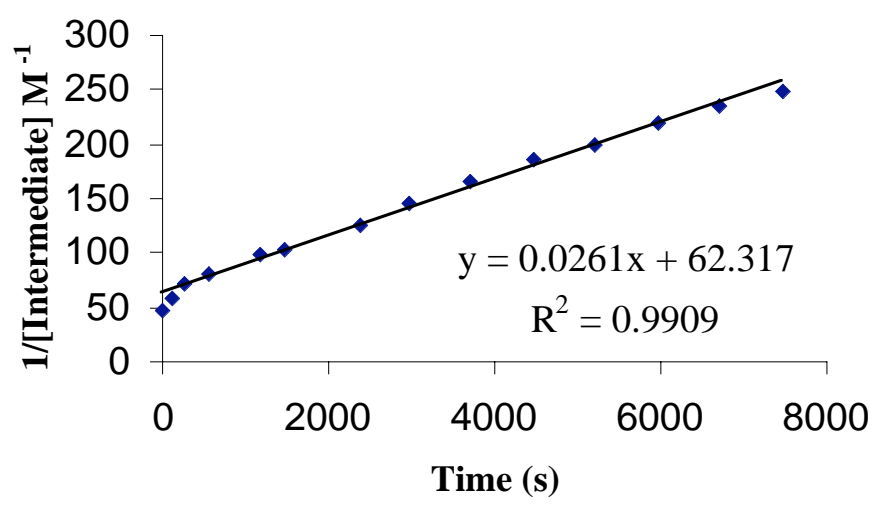


Figure S3. IR ( $\mathrm{KBr}$ disk) of $\mathrm{OsO}_{2}(\mathrm{py})_{2}\left(\mathrm{OSiEt}_{3}\right)(\mathrm{OH})$ in the reaction between $\mathrm{OsO}_{4}(\mathrm{py})$ and $\mathrm{Et}_{3} \mathrm{SiH}$ in pentane.

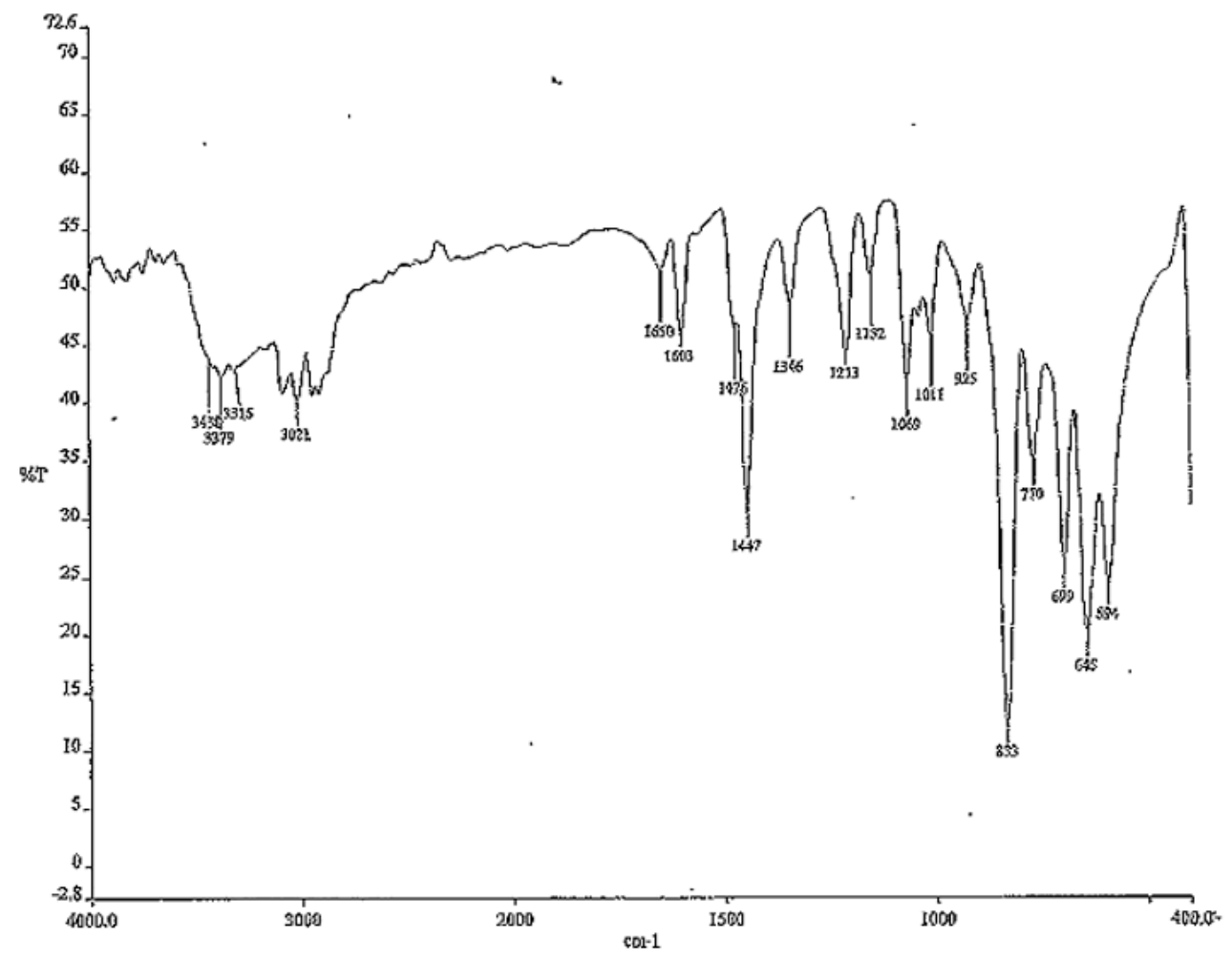

Table S1. The IR ( $\mathrm{KBr}$ disk) of the isolated material in the reaction of $\mathrm{Et}_{3} \mathrm{SiH}_{\text {with }} \mathrm{OsO}_{4}(\mathrm{py})$.

\begin{tabular}{|l|l|l|}
\hline KBr disk peaks cm & Assignment of sample peaks \\
\hline $2362(\mathrm{w}), 1699(\mathrm{w}), 652(\mathrm{w})$, & $3379(\mathrm{br})$ & $\mathrm{OH}$ \\
$1559(\mathrm{w}) 1496(\mathrm{~s}), 1456(\mathrm{w})$ & & \\
$1262(\mathrm{w}) 1095(\mathrm{br}), 823(\mathrm{w}) 574(\mathrm{~s})$ & & \\
\cline { 2 - 3 } & $3088(\mathrm{w}), 3021(\mathrm{w}), 2950(\mathrm{w})$, & $\mathrm{CH}$ \\
& $2916(\mathrm{w}), 1650(\mathrm{w}), 1603(\mathrm{w})$, & \\
& $1447(\mathrm{w}), 1343(\mathrm{w}), 1213(\mathrm{w})$, & \\
& $1011(\mathrm{w}), 770(\mathrm{~s}), 699(\mathrm{~s})$ & \\
\hline
\end{tabular}

